\title{
REVISTA IBERO-AMERICANA DE ESTUDOS EM EDUCAÇÃO
}

\author{
v. 5, n. 2, maio/agosto de 2010
}

\section{EDITORIAL}

É com grande satisfação que publicamos o v. 5, n. 2, 2010 da Revista IberoAmericana de Estudos em Educação.

Nosso objetivo continua ser, prioritariamente, a publicação de artigos resultantes dos trabalhos encaminhados para apresentação nos Encontros Ibero-Americanos de Educação e recomendados pelos pareceristas após a análise criteriosa e seletiva dos mesmos, objetivando sua apresentação. No entanto, artigos encaminhados diretamente para a revista também serão avaliados e poderão ser publicados desde que estejam dentro das normas do periódico e sejam aprovados pelos nossos pareceristas.

Esperamos continuar contribuindo com a Pós-Graduação na área de Educação e afins, e para a integração de pesquisadores ibero-americanos, fortalecendo principalmente os laços entre Brasil e Espanha, países que deram início à organização e realização dos Encontros Ibero-Americanos de Educação.

O Editor 